\title{
ANALISIS TINGKAT KESEHATAN BANK DENGAN METODE CAMEL PADA PT BANK ARTOS INDONESIA TbK PERIODE 2014-2017
}

\author{
Randi Syahputra \\ Program Studi Akuntansi, Politeknik LP3I Medan \\ Ahsanul Fuad Saragih \\ Program Studi Akuntansi, Politeknik LP3I Medan
}

*Corresponding author: E-mail: randis508@gmail.c, om, Ahsanul_fuad@yahoo.com

\section{Abstrak [Cambria, Size: 10, Bold]}

Usaha perbankan di indonesia semakin pesat dan sangat kompleks, hal ini mengakibatkan peningkatan resiko yang dihadapi bank-bank di era saat ini maupun di masa yang akan datang. Bank merupakan lembaga keuangan yang tugas utamanya adalah menghimpun dana dari masyarakat dalam bentuk tabungan dan menyalurkan kembali ke masyarakat dalam bentuk kredit serta memberikan jasa bank lainnya. Oleh karena itu penting bagi bank untuk menjaga kepercayaan masyarakat, sebab kegiatan usahanya mengendalikan kepercayaan masyarakat. Penilaian tingkat kesehatan bank ini dijadikan sebagai suatu tolak ukur untuk mengevaluasi pengelolahan bank sesuai dengan ketetapan Bank Indonesia. Tujuan penelitian ini adalah untuk menganalisis tingkat kesehatan PT. Bank Artos Indonesia Tbk. Periode 2014-2017. Berdasarkan hasil analisis tingkat kesehatan bank dengan menggunakan rasio CAMEL periode 2014-2017, keseluruhan dapat dikatakan bahwa secara umum kinerja dan kesehatan PT. Bank Artos Indonesia Tbk dalam kondisi "TIDAK SEHAT".

\section{Kata Kunci : Kesehatan Bank, Rasio CAMEL}

\begin{abstract}
Banking business in Indonesia is increasingly rapid and very complex, this resulted in an increased risk faced by banks in the current era and in the future. Bank is a financial institution whose main task is to raise funds from the community in the form of savings and channeling back to the community in the form of credit and provide other bank services. Therefore, it is important for banks to maintain public trust, because their business activities control public confidence. This rating of bank soundness is used as a benchmark to evaluate bank mangement in accordance with the provisions of Bank Indonesia. The purpose of this study is to analyze the health level of PT. Bank Artos Indonesia Tbk. Period 2014-2017. Based on the results of bank soundness analysis using CAMEL period 2014-2017, overall it can be said that in general the performance and health of PT. Bank Artos Indonesia Tbk in condition "NOT HEALTHY".
\end{abstract}




\section{PENDAHULUAN}

Bank Umum merupakan lembaga keuangan yang bertugas menghimpun dana dari masyarakat dalam bentuk simpanan (funding) dan menyalurkan kembali kepada masyarakat dalam bentuk kredit (lending). Salah satu unsur yang penting bagi bank adalah unsur kinerja dan kesehatannya, karena dengan mengetahui unsur tersebut kita dapat menilai serta membandingkan kualitas suatu bank terhadap bank yang lain. Unsur tersebut penting untuk diketahui oleh para investor, para nasabah giro, deposito, maupun tabungan yang menanamkan dananya pada bank tertentu. Untuk menilai tingkat kesehatan bank dapat dilakukan dengan indikator laporan keuangan bank yang bersangkutan. Bank Indonesia mengeluarkan kebijakan penilaian terhadap kesehatan bank dengan metode CAMEL berdasarkan PBI No. 6/10/2004. CAMEL yakni singkatan dari Capital, Asset Quality, Management, Earning dan Liquidity. CAMEL juga digunakan sebagai indikator dalam menyusun peringkat serta memprediksi prospek suatu bank di masa yang akan datang.

Menurut penelitian terdahulu yang dilakukan oleh Hendra Saputra (2016) tentang Analisis Tingkat Kesehatan Bank dengan metode CAMEL pada Bank Rakyat Indonesia (Persero) Tbk periode 2010-2014, mengatakan pada Bank Rakyat Indonesia, menunjukkan faktor permodalan CAR (Capital Adequency Ratio) pada bank ini dikatakan sehat karena presentasi hasilnya diatas standar peraturan Bank Indonesia tahun 2004 yaitu 12\%, faktor kualitas aktiva produktif dengan rasio NPL (Non Performing Loan) menunjukkan presentasi kurang dari 3\% artinya semakin kecil NPL nya maka resiko kredit macet yang ditanggung bank semakin kecil dan semakin sehat pula kualitas aktiva produktifnya, Faktor Manajemen dengan rasio NPM (Net Profit
Margin) mendapatkan predikat cukup sehat artinya manager dalam mengatur dan mengendalikan bank harus lebih ditingkatkan untuk mengasilkan laba yang maksimal, faktor rentabilitas dengan rasio ROA dan BOPO dalam predikat sehat serta faktor likuiditas dengan rasio LDR (loan to deposit ratio) mendapat predikat sehat. Perbedaan penelitian ini dengan sebelumnya terletak pada objek dan periode penelitian yaitu pada PT. Bank Artos Indonesia Tbk periode 2014-2017.

Bank Artos Indonesia adalah lembaga keuangan yang bergerak dibidang jasa keuangan, bank ini didirikan di bandung. Pada laporan keuangan Bank Artos Indonesia terjadi kerugian di tahun 2015 dan tahun 2016 padahal aset dan pendapatannya cukup besar. Oleh karena itu penulis ingin mengetahui apakah tingkat kesehatan bank ini masih dalam kategori sehat dari tahun 2014 sampai 2017 serta apa yang menyebabkan bank ini mengalami kerugian. Dari uraian latar belakang diatas penulis ingin mengetahui peran analisa rasio CAMEL secara efisiensi dapat mengukur kinerja kesehatan keuangan bank tersebut. Berdasarkan hal tersebut, maka penulis tertarik untuk melakukan penelitian yang berjudul "Analisis Tingkat Kesehatan Bank dengan metode CAMEL pada PT. Bank Artos Indonesia Tbk, Periode 2014-2017".

\section{Definisi Perbankan}

Perbankan adalah segala sesuatu yang menyangkut tentang bank, mencakup kelembagaan, kegiatan usaha, serta cara dan proses dalam melaksanakan kegiatan usahanya. Dewasa ini banyak terdapat literatur yang memberikan pengertian atau definisi tentang Bank, antara lain : 
Menurut Kasmir (2014:14), Bank adalah badan usaha yang menghimpun dana dari masyarakat dalam bentuk simpanan dan menyalurkannya kembali kepada masyarakat dalam bentuk kredit dan atau bentuk-bentuk lainnya dalam rangka meningkatkan taraf hidup rakyat banyak. Sedangkan usaha perbankan meliputi tiga kegiatan, yaitu menghimpun dana, menyalurkan dana dan memberikan jasa bank lainnya.

\section{Pengertian Laporan Keuangan}

Laporan keuangan adalah catatan informasi keuangan suatu perusahaan pada suatu periode akuntansi yang dapat digunakan untuk menggambarkan kinerja perusahaan tersebut. Laporan keuangan terdiri dari laporan laba rugi, laporan perubahan ekuitas, laporan neraca, laporan arus kas dan catatan atas laporan keuangan. Dimana laporan keuangan diperlukan sebagai dasar dalam pengambilan suatu keputusan ekonomi. Menurut Kasmir (2014:7) "Laporan Keuangan adalah Laporan yang menunjukkan kondisi keuangan perusahaan pada saat ini atau dalam suatu periode tertentu".

\section{Analisa Laporan Keuangan}

Setelah pembuatan laporan keuangan, maka laporan keuangan tersebut akan dianalisis. Hasil analisis laporan keuangan ini akan memberikan informasi tentang kelemahan dan kekuatan yang dimiliki perusahaan. Menurut Kasmir (2012:66), analisis laporan keuangan adalah Penyusunan laporan keuangan berdasarkan data yang relevan, serta dilakukan dengan prosedur akuntansi dan penilaian yang benar sehingga akan terlihat kondisi keuangan perusahaan yang sesungguhnya.

\section{Analisis Tingkat Kesehatan Bank Menggunakan Rasio CAMEL}

Definisi rasio keuangan CAMEL menurut Kamus Perbankan Bank Indonesia (2015) adalah :

Aspek yang paling banyak berpengaruh terhadap kondisi keuangan bank yang mempengaruhi pula tingkat kesehatan bank. CAMEL merupakan tolak ukur yang menjadi objek pemeriksaan bank yang dilakukan oleh pengawas bank. CAMEL terdiri atas lima kriteria, yaitu modal (Capital), aktiva (Asset), manajemen (Management), pendapatan (Earnings), dan likuiditas (Liquidity).

\section{Faktor Permodalan (CapitaI)}

CAR (Capital Adequacy Ratio) merupakan rasio kecukupan modal yang menunjukkan kemampuan perbankan dalam menyediakan dana yang digunakan untuk mengatasi kemungkinan risiko kerugian.

Menurut Kasmir (2012:11), Penilaian didasarkan kepada permodalan yang dimiliki oleh salah satu bank. Salah satu penilaian adalah dengan metode CAR (capital adequacy ratio), yaitu dengan cara membandingkan modal tehadap aktiva tertimbang menurut risiko (ATMR). 
Tabel 1. Kriteria Aspek Permodalan

\begin{tabular}{|c|c|}
\hline Rasio & Peringkat \\
\hline CAR $\geq 12 \%$ & 1 (Sangat Sehat) \\
\hline $9 \% \leq \mathrm{CAR}<12 \%$ & 2 (Sehat) \\
\hline $8 \% \leq \mathrm{CAR}<9 \%$ & 3 (Cukup Sehat) \\
\hline $6 \% \leq \mathrm{CAR}<8 \%$ & 4 (Kurang Sehat) \\
\hline CAR $\leq 6 \%$ & 5 (Tidak Sehat) \\
\hline
\end{tabular}

Sumber : Surat Edaran Bank Indonesia Nomor 6/23/DPNP tahun 2004

\section{Faktor Kualitas Aset (Assets Quality)}

Dalam kondisi normal sebagian besar aktiva suatu bank terdiri dari kredit dan aktiva lain yang dapat menghasilkan atau menjadi sumber pendapatan bagi bank, sehingga jenis aktiva tersebut sebagai aktiva produktif.
Menurut Kasmir (2012:11) Penilaian didasarkan kepada kualitas aktiva produktif yang dimiliki bank adalah rasio aktiva produktif yang diklasifikasikan terhadap aktiva produktif. Rasio ini digunakan untuk mengukur tingkat kemungkinan diterimanya kembali dana yang ditanamkan.

Tabel 2. Kriteria Kualitas AktivaProduktif

\begin{tabular}{|c|c|}
\hline Rasio & Peringkat \\
\hline$\leq 2 \%$ & 1 (Sangat Sehat) \\
\hline $2 \%<\mathrm{KAP} \leq 3 \%$ & 2 (Sehat) \\
\hline $3 \%<\mathrm{KAP} \leq 6 \%$ & 3 (Cukup Sehat) \\
\hline $6 \%<\mathrm{KAP} \leq 9 \%$ & 4 (Kurang Sehat) \\
\hline $\mathrm{KAP}>9 \%$ & 5 (Tidak Sehat) \\
\hline
\end{tabular}

Sumber : Surat Edaran Bank Indonesia Nomor6/23/DPNP tahun 2004

Faktor Manajemen (Management)

Manajemen atau pengelolaan suatu bank akan menentukan sehat tidaknya suatu bank. Mengingat hal tersebut, maka pengelolaan suatu manajemen sebuah bank mendapatkan perhatian yang besar dalam penilaian tingkat kesehatan bank, suatu bank diharapkan dapat menciptakan dan memelihara kesehatannya.
Penilaian terhadap aspek manajemen menggunakan rasio Net Profit Margin. Menurut Kasmir (2017:235)Net Profit Margin merupakan "rasio yang digunakan untuk mengukur kemampuan bank dalam menghasilkan net income dari kegiatan operasi pokoknya".

Tabel 3. Kriteria Aspek Manajemen (NPM)

\begin{tabular}{|c|c|}
\hline Rasio & Peringkat \\
\hline $\mathrm{NPM} \geq 100 \%$ & 1 (Sangat Sehat) \\
\hline $81 \% \leq \mathrm{NPM}<100 \%$ & 2 (Sehat) \\
\hline $66 \% \leq \mathrm{NPM}<81 \%$ & 3 (Cukup Sehat) \\
\hline
\end{tabular}




\begin{tabular}{|c|c|}
\hline $51 \% \leq \mathrm{NPM}<66 \%$ & 4 (Kurang Sehat) \\
\hline $\mathrm{NPM}<51 \%$ & 5 (Tidak Sehat) \\
\hline
\end{tabular}

Sumber : Surat Edaran Bank Indonesia Nomor 6/23/DPNP tahun 2004

\section{Faktor Rentabilitas (Earning)}

Menurut Kasmir Penilaian dalam unsur ini didasarkan kepada dua macam, yaitu :

a) Rasio laba terhadap total asset (Return on Assets). Rasio ini digunakan untuk mengukur efektifitas bank didalam memperoleh keuntungan secara keseluruhan.

b) Rasio Beban Operasional terhadap Pendapatan Operasional (BOPO). BOPO merupakan perbandingan antara beban operasional terhadap pendapatan operasional.

Tabel 4. Kriteria Aspek Rentabilitas

\begin{tabular}{|c|c|c|}
\hline Peringkat & ROA & BOPO \\
\hline 1 (Sangat Sehat) & ROA $>1,5 \%$ & BOPO $\leq 94 \%$ \\
\hline 2 (Sehat) & $1,25 \%<\mathrm{ROA} \leq 1,5 \%$ & $94 \%<\mathrm{BOPO} \leq 95 \%$ \\
\hline 3 (Cukup Sehat) & $0,5 \%<\mathrm{ROA} \leq 1,25 \%$ & $95 \%<\mathrm{BOPO} \leq 96 \%$ \\
\hline 4 (Kurang Sehat) & $0<\mathrm{ROA} \leq 0,5 \%$ & $96 \%<\mathrm{BOPO} \leq 97 \%$ \\
\hline 5 (Tidak Sehat) & $\mathrm{ROA} \leq 0$ & $\mathrm{BOPO}>97 \%$ \\
\hline
\end{tabular}

\section{Faktor Likuiditas (Liquidity)}

Aspek likuiditas ini didasarkan atas kemauan bank dalam membayar semua utang-utangnya terutama simpanan tabungan, giro dan deposito pada saat ditagih dan dapat memenuhi semua permohonan kredit yang layak disetujui.
Menurut Pandia (2012:118), Loan to Deposito Ratio (LDR) merupakan "Rasio yang menyatakan seberapa jauh bank telah menggunakan uang para penyimpan (depositor) untuk memberikan pinjaman kepada para nasabahnya".

Tabel 5. Kriteria Peringkat Aspek Likuiditas

\begin{tabular}{|c|c|}
\hline Rasio LDR & Peringkat \\
\hline LDR $\leq 75 \%$ & 1 (Sangat Sehat) \\
\hline $75 \%<$ LDR $\leq 85 \%$ & 2 (Sehat) \\
\hline $85 \%<$ LDR $\leq 100 \%$ & 3 (Cukup Sehat) \\
\hline $100 \%<$ LDR $\leq 120 \%$ & 4 (Kurang Sehat) \\
\hline LDR $>120 \%$ & 5 (Tidak Sehat) \\
\hline
\end{tabular}

Sumber : Surat Edaran Bank Indonesia Nomor 6/23/DPNP tahun 2004

\section{Penilaian Kesehatan Bank}

Penilaian tingkat kesehatan bank di Indonesia sampai saat ini secara garis besar 
didasarkan pada faktor CAMEL (Capital, mengalami kesulitan ataupun Asset Quality, Management, Earning, ketidaksehatan pada bank tersebut. Secara Liquidity). Kelima faktor tersebut memang umum faktor CAMEL, relevan dipergunakan merupakan faktor yang menentukan untuk semua bank, tetapi bobot masingkondisi suatu bank. Apabila sesuatu bank masing faktor akan berbeda untuk masingmengalami permasalahan pada salah satu masing jenis bank. CAMEL untuk bank faktor tersebut, maka bank tersebut umum ditetapkan sebagai berikut:

Tabel 6. Bobot CAMEL Bank Umum

\begin{tabular}{|c|c|c|}
\hline No & Faktor CAMEL & Bank Umum \\
\hline 1 & Permodalan & $25 \%$ \\
\hline 2 & Kualitas Aktiva Produktif & $30 \%$ \\
\hline 3 & Kualitas Manajemen & $25 \%$ \\
\hline 4 & Rentabilitas & $10 \%$ \\
\hline 5 & Likuiditas & $10 \%$ \\
\hline
\end{tabular}

Sumber : Bank Indonesia Indonesia:

Berikut adalah tabel tingkat kesehatan bank metode CAMEL, menurut Bank

Tabel 7. Hasil Penilaian Tingkat Kesehatan Bank

\begin{tabular}{|c|c|}
\hline Nilai CAMEL & Tingkat Kesehatan Keuangan \\
\hline $81 \%-100 \%$ & Sehat \\
\hline $66 \%-81 \%$ & Cukup Sehat \\
\hline $51 \%-66 \%$ & Kurang Sehat \\
\hline $0 \%-50 \%$ & Tidak Sehat \\
\hline
\end{tabular}

Sumber : Bank Indonesia

Setelah mengetahui hasil data sekunder. Penelitian ini menggunakan perhitungan masing-masing CAMEL diatas, data eksternal berupa data laporan maka dapat diketahui hasil penilaian akhir keuangan tahun 2012-2016 yang diperoleh berdasarkan peringkat komposit dari setiap dari website Bursa Efek Indonesia komponen tersebut sesuai dengan www.idx.co.id. Serta ditunjang dengan studi peraturan Bank Indonesia No kepustakaan untuk memperoleh sumber 13/3/PBI/2011

\section{METODE PENELITIAN}

Penelitian ini dilaksanakan pada PT. Bank Artos Indonesia Tbk. Yang terdaftar di situs resmi Bursa Efek Indonesia www.idx.co.id dari tahun 2014- 2017. Jenis dan sumber data yang penulis gunakan dalam penulisan ini penulis menggunakan referensi yang mendukung penelitian ini yaitu berupa laporan keuangan PT. Bank Artos Indonesia Tbk. Sumber data yang digunakan adalah data internal dan eksternal yang berasal dari publikasi laporan keuangan oleh Bursa Efek Indonesia (www.idx.co.id) yang terdiri dari Laporan Neraca, Laporan Laba-Rugi dan Catatan atas Laporan Keuangan

Dalam penulisan ilmiah ini, penulis menggunakan data sekunder dalam upaya 
pengumpulan data dan penulis memperoleh data dari berbagai sumber, diantaranya adalah:

1. Metode Studi Dokumentasi

Metode ini dilakukan dengan cara mencari dan mempelajari data serta mencatat data tertulis mengenai hal-hal yang berupa catatan atau dokumen dari perusahaan yang berhubungan dengan objek penelitian. Metode dokumentasi dalam penelitian ini adalah mengambil data laporan keuangan perusahaan di Bursa Efek Indonesia (BEI) : www.idx.co.id.

2. Studi Pustaka

Yaitu teknik pengumpulan data dengan mencari berbagai jenis buku-buku referensi yang berkaitan dengan Tugas Akhir penulis dan sumber-sumber lainnya sebagai pondasi dan penyelesaian Tugas Akhir hasil penelitian yang dapat lebih memuaskan.

Metode analisis data yang penulis gunakan dalam penelitian ini adalah metode analisis deskriptif kuantitatif adalah statistik yang digunakan untuk menganalisis data dengan cara mendeskripsikan atau menggambarkan

Tabel 8. Capital Adequacy Ratio Tahun 2014 s/d 2017 (dalam Milyar Rupiah)

\begin{tabular}{|c|r|r|r|r|}
\hline Keterangan & \multicolumn{1}{|c|}{\begin{tabular}{l}
\multicolumn{1}{c|}{2014} \\
$(\mathrm{Rp})$
\end{tabular}} & \multicolumn{1}{c|}{\begin{tabular}{l}
\multicolumn{1}{c|}{2016} \\
$(\mathrm{Rp})$
\end{tabular}} & \multicolumn{1}{c|}{$(\mathrm{Rp})$} & \multicolumn{1}{c|}{$(\mathrm{Rp})$} \\
\hline Modal & 104.829 & 107.213 & 147.268 & 147.408 \\
\hline ATMR & 626.300 & 541.355 & 608.050 & 627.986 \\
\hline Nilai CAR & 0,1674 & 0,1980 & 0,2422 & 0,2347 \\
\hline Rasio CAR & $\mathbf{1 6 , 7 4 \%}$ & $\mathbf{1 9 , 8 0 \%}$ & $\mathbf{2 4 , 2 2 \%}$ & $\mathbf{2 3 , 4 7 \%}$ \\
\hline
\end{tabular}

Sumber Data : Data Olahan (2018)

CAR merupakan suatu indikator yang digunakan untuk mengetahui data yang telah terkumpul sebagaimana adanya, tanpa membuat kesimpulan yang berlaku untuk umum atau generalisasi dan merupakan penelitian dengan memperoleh data yang berbentuk angka atau data kualitatif yang diangkakan.

\section{A. HASIL PENELITIAN}

Penilaian tingkat kesehatan bank umum dengan menggunakan metode CAMEL (capital, asset quality, management, earning, liquidity) pada PT Bank Artos Indonesia Tbk. Hasil analisis dengan metode CAMEL menunjukkan kondisi kesehatan bank yang digolongkan kedalam peringkat sehat, cukup sehat, kurang sehat dan tidak sehat yang merupakan peringkat akhir hasil penilaian tingkat kesehatan bank.

\section{Faktor Permodalan (Capital)}

Menerangkan hasil penelitian beserta perhitungan yang terdapat pada CAMEL PT. Bank Artos Indonesia Tbk periode 2014 s/d 2017.

Untuk perhitungan capital menggunakan rasio CAR (Capital Adequacy Ratio)

$$
\text { CAR }=\frac{\text { Modal }}{\text { ATMR }} \times 100 \%
$$


aktiva yang berakibat pada kerugian bank yang disebabkan oleh aktiva beresiko. CAR juga digunakan sebagai pedoman bagi perbankan untuk membandingkan modal terhadap aktiva tertimbang menurut resiko (ATMR). Semakin tinggi nilai CAR maka semakin besar kemampuan modal bank untuk menutupi kemungkinan kerugian yang terjadi. Berdasarkan analisis perhitungan pada tabel diatas mengenai rasio CAR bank Artos Indonesia Tbk pada tahun 2014 perolehan nilai rasio CAR sebesar 16,74\%, tahun 2015 sebesar 19,80\%, tahun 2016 sebesar 24,22\%, tahun 2017 sebesar 23,47\%. Dari Hasil Perhitungan CAR maka dapat dilakukan perhitungan nilai kredit rasio CAR dari setiap tahun, dengan rumus berikut ini :

Tabel 9.PT. Bank Artos Indonesia Tbk, KAP Tahun 2014 s/d 2017 (dalam Milyar Rupiah)

\begin{tabular}{|c|c|c|c|c|c|}
\hline \multirow{3}{*}{ Kategori } & \multirow{3}{*}{$\begin{array}{l}\text { Tingkat } \\
\text { Resiko }\end{array}$} & \multicolumn{4}{|c|}{ Tahun } \\
\hline & & 2014 & 2015 & 2016 & 2017 \\
\hline & & $(\mathrm{Rp})$ & (Rp) & (Rp) & $(\mathrm{Rp})$ \\
\hline (DPK) & 25 & 12.401 & 19.642 & 11.286 & 8.863 \\
\hline$(\mathrm{KL})$ & 50 & 4.301 & 1.458 & 205 & 564 \\
\hline (D) & 75 & 3.773 & & 2.424 & 4.564 \\
\hline$(\mathrm{M})$ & 100 & 6.473 & 7.925 & 28.867 & 22.716 \\
\hline Total APYD & & 26.949 & 29.026 & 42.784 & 36.709 \\
\hline Total Aktiva Poduktif & & 738.141 & 643.955 & 631.169 & 624.350 \\
\hline Nilai KAP & & 0,0365 & 0,0451 & 0,0678 & 0,0587 \\
\hline Rasio KAP & & $4 \%$ & $5 \%$ & $7 \%$ & $6 \%$ \\
\hline
\end{tabular}

Sumber Data : Data Olahan 2018

Berdasarkan analisis perhitungan pada tabel diatas, hasil rasio KAP tahun 2014 perolehan nilai rasio KAP sebesar 4\%, tahun 2015 sebesar 5\%, tahun 2016 sebesar 7\% dan tahun 2017 sebesar 6\%. Dari hasi rasio KAP maka dapat dilakukan perhitungan nilai kredit untuk rasio KAP sebagai berikut :

Nilai Kredit $=1+\frac{22,5 \%-\text { Rasio }}{0,15 \%} \times 1$
Nilai Kredit $=1+\frac{\text { Ratio }}{0,1 \%} \times 1$

\section{Faktor Kualitas Aset (Assets Quality)}

Dalam menilai kualitas aset
$\begin{aligned} & \text { digunakan perhitungan } \\ & \text { menggunakan rasio Kualitas }\end{aligned}$ Aktiva
Produktif (KAP). Rasio ini merupakan
perbandingan antara jumlah aktiva
produktif yang diklasifikasikan dengan
total aktiva produktif.

$$
\text { KAP }=\frac{\text { APYD }}{\text { Total Aktiva Produktif }}
$$




$$
\text { NPM }=\frac{\text { Laba Bersih }}{\text { Pendapatan Operasional }} \quad \times 100 \%
$$

Tabel 10. Net Profit Margin Tahun 2014 s/d 2017 (dalam Milyar Rupiah)

\begin{tabular}{|c|r|r|r|r|}
\hline \multirow{2}{*}{ Keterangan } & \multicolumn{4}{|c|}{ Tahun } \\
\cline { 2 - 5 } & \multicolumn{1}{|c|}{2014} & \multicolumn{1}{c|}{2015} & \multicolumn{1}{c|}{2016} & \multicolumn{1}{c|}{2017} \\
\hline Laba Bersih & 1.131 & $(309)$ & $(33.330)$ & 139 \\
\hline Pendapatan Operasional & 1.514 & $(449)$ & $(36.506)$ & 248 \\
\hline Nilai NPM & 0,75 & $-0,69$ & $-0,91$ & 0,56 \\
\hline Rasio NPM & $\mathbf{7 5 \%}$ & $\mathbf{- 6 9 \%}$ & $\mathbf{- 9 1 \%}$ & $\mathbf{5 6 \%}$ \\
\hline
\end{tabular}

Sumber Data : Data Olahan (2018)

Berdasarkan analisis perhitungan pada tabel diatas, hasil perhitungan Net Profit Margin (NPM) bank Artos Indonesia Tbk pada tahun 2014 memperoleh nilai rasio NPM sebesar 75\%, tahun 2015 sebesar 69\%, tahun 2016 sebesar 91\% dan tahun 2017 sebesar 56\%.

\section{Faktor Rentabilitas (Earnings)}

\section{Return On Asset (ROA)}

Return on asset digunakan untuk mengukur kemampuan manajemen bank dalam memperoleh keuntungan (laba bersih sebelum pajak) serta mengukur efektifitas bank di dalam memperoleh keuntungan secara keseluruhan. Semakin besar ROA, maka semakin besar pula tingkat keuntungan yang dicapai oleh bank, sehingga kemampuan suatu bank dalam menjalankan aktivitasnya dapat berjalan dengan baik.

$$
\text { ROA }=\frac{\text { Laba Sebelum Pajak }}{\text { Total Aktiva }} \times 100 \%
$$

Tabel 11. Return On Asset Tahun 2014 s/d 2017 (dalam Milyar Rupiah)

\begin{tabular}{|c|r|r|r|r|}
\hline \multirow{2}{*}{ Keterangan } & \multicolumn{4}{|c|}{ Tahun } \\
\cline { 2 - 5 } & \multicolumn{1}{|c|}{2014} & \multicolumn{1}{|c|}{2015} & \multicolumn{1}{c|}{2016} & \multicolumn{1}{c|}{2017} \\
\hline EBIT & 2.076 & 77 & $(37.879)$ & 185 \\
\hline Total Aset & 840.775 & 745.646 & 774.779 & 789.390 \\
\hline Nilai ROA & 0,0025 & 0,0001 & $-0,0489$ & 0,0002 \\
\hline Rasio ROA & $\mathbf{0 , 2 5 \%}$ & $\mathbf{0 , 0 1 \%}$ & $\mathbf{- 4 , 8 9 \%}$ & $\mathbf{0 , 0 2 \%}$ \\
\hline
\end{tabular}

Sumber Data : Data Olahan (2018)

Berdasarkan analisis perhitungan hasil perhitungan rasio ROA maka dapat tabel diatas, hasil perhitungan rasio Return dilakukan perhitungan nilai kredit untuk On Assets (ROA) bank Artos Indonesia Tbk rasio ROA menurut ketentuan Bank pada tahun 2014 sebesar 0,25\%, tahun Indonesia yaitu: 
Nilai Kredit $=\frac{\text { Rasio }}{0,015 \%}$

\section{BOPO}

Rasio BOPO (Beban Operasional Pendapatan Operasional) digunakan untuk mengukur tingkat efisiensi dan kemampuan bank dalam melakukan kegiatan operasinya, Rasio BOPO diperoleh dengan cara membagi biaya operasional dengan pendapatan operasional.

Tabel 12. BOPO Tahun 2014 s/d 2017 (dalam Milyar Rupiah)

\begin{tabular}{|c|r|r|r|r|}
\hline \multirow{2}{*}{ Keterangan } & \multicolumn{4}{|c|}{ Tahun } \\
\cline { 2 - 5 } & \multicolumn{1}{|c|}{2014} & \multicolumn{1}{|c|}{2015} & \multicolumn{1}{c|}{2016} & \multicolumn{1}{c|}{2017} \\
\hline $\begin{array}{c}\text { Beban } \\
\text { Operasional }\end{array}$ & 89.685 & 98.972 & 121.139 & 28.005 \\
\hline $\begin{array}{c}\text { Pendapatan } \\
\text { Operasional }\end{array}$ & 91.199 & 98.523 & 84.632 & 28.253 \\
\hline Nilai BOPO & 0,98 & 1,00 & 1,43 & 0,99 \\
\hline Rasio BOPO & $\mathbf{9 8 \%}$ & $\mathbf{1 0 0 \%}$ & $\mathbf{1 4 3 \%}$ & $\mathbf{9 9 \%}$ \\
\hline
\end{tabular}

Sumber Data : Data Olahan (2018)

Berdasarkan analisis perhitungan tabel diatas, hasil perhitungan rasiol BOPO tahun 2014 sebesar 98\%, tahun 2015 sebesar 100\%, tahun 2016 sebesar 143\% dan tahun 2017 sebesar 99\%. Dari hasil perhitungan rasio BOPO maka dapat dilakukan perhitungan nilai kredit untuk rasio BOPO menurut ketentuan Bank Indonesia yaitu sebagai berikut :

Nilai Kredit $=\frac{100 \%-B O P O}{0,08 \%}$

\section{Faktor Likuiditas (Liquidity)}

Analisis terhadap komponen likuiditas merupakan analisis yang dilakukan terhadap kemampuan ataupun kemauan bank dalam memenuhi kewajiban-kewajiban jangka pendeknya atau kewajiban yang sudah jatuh tempo.

$$
\text { LDR }=\frac{\text { Kredit yang Diberikan }}{\text { Dana Pihak Ketiga }}
$$

Tabel 13. Loan to Deposit Ratio Tahun 2014 s/d 2017 (dalam Milyar Rupiah)

\begin{tabular}{|c|r|r|r|r|}
\hline \multirow{2}{*}{ Keterangan } & \multicolumn{4}{|c|}{ Tahun } \\
\cline { 2 - 5 } & \multicolumn{1}{|c|}{2014} & \multicolumn{1}{c|}{2015} & \multicolumn{1}{c|}{2016} & \multicolumn{1}{c|}{2017} \\
\hline Kredit Yang Diberikan & 545.471 & 466.162 & 461.431 & 469.134 \\
\hline Dana Pihak Ketiga & 546.393 & 530.549 & 565.140 & 583.219 \\
\hline Nilai LDR & 0,998 & 0,878 & 0,816 & 0,804 \\
\hline Rasio LDR & $\mathbf{1 0 0 \%}$ & $\mathbf{8 8 \%}$ & $\mathbf{8 2 \%}$ & $\mathbf{8 0 \%}$ \\
\hline
\end{tabular}

Sumber Data : Data Olahan (2018) 
Berdasarkan analisis perhitungan tabel diatas, menunjukkan hasil Loan to Deposit Ratio (LDR) untuk tahun 2014 sebesar 100\%, tahun 2015 sebesar 88\%, tahun 2016 sebesar $82 \%$ dan tahun 2017 sebesar $80 \%$. Berikut ini rumus untuk menghitung nilai kredit menurut ketentuan Bank Indonesia.
Nilai Kredit $=1+\frac{(115-\text { Rasio })}{1,00} \times 4$

Hasil penilaian terhadap analisis CAMEL, untuk tahun 2014 sampai dengan tahun 2017 dapat dilihat melalui tabel berikut ini :

Tabel 14. Hasil Evaluasi CAMEL PT. Bank Artos Indonesia Tbk. Tahun 2014 s/d 2017

\begin{tabular}{|c|c|c|c|c|c|c|}
\hline Tahun & Faktor Penilaian & $\begin{array}{c}\text { Indikator } \\
\text { Kerja }\end{array}$ & $\begin{array}{c}\text { Nilai Rasio } \\
(\%)\end{array}$ & $\begin{array}{c}\text { Nilai } \\
\text { Kredit }\end{array}$ & \begin{tabular}{|c|} 
Bobot \\
$(\%)$ \\
\end{tabular} & $\begin{array}{c}\text { Nilai } \\
\text { CAMEL }\end{array}$ \\
\hline \multirow{6}{*}{2014} & Permodalan & CAR & 16,74 & 100 & 25 & 25 \\
\hline & $\begin{array}{c}\text { Kualitas Aktiva } \\
\text { Produktif }\end{array}$ & KAP & 4 & 100 & 30 & 30 \\
\hline & Management & NPM & 75 & 75 & 25 & 18,75 \\
\hline & Earning & 1.ROA & 0,25 & 17 & 5 & 0,85 \\
\hline & & 2.BOPO & 98 & 25 & 5 & 1,25 \\
\hline & Likuiditas & LDR & 100 & 64 & 10 & 6,4 \\
\hline \multicolumn{6}{|c|}{ Jumlah Nilai CAMEL } & 82,25 \\
\hline \multirow{6}{*}{2015} & Permodalan & CAR & 19,80 & 100 & 25 & 25 \\
\hline & $\begin{array}{l}\text { Kualitas Aktiva } \\
\text { Produktif }\end{array}$ & KAP & 5 & 100 & 30 & 30 \\
\hline & Management & NPM & -69 & -69 & 25 & $-17,25$ \\
\hline & Earning & 1.ROA & 0,01 & 1 & 5 & 0,05 \\
\hline & & 2.BOPO & 101 & 0 & 5 & 0 \\
\hline & Likuiditas & LDR & 88 & 100 & 10 & 10 \\
\hline \multicolumn{6}{|c|}{ Jumlah Nilai CAMEL } & 47,80 \\
\hline & Permodalan & CAR & 24,22 & 100 & 25 & 25 \\
\hline 2016 & $\begin{array}{l}\text { Kualitas Aktiva } \\
\text { Produktif } \\
\text { Management }\end{array}$ & KAP & 7 & 100 & 30 & 30 \\
\hline
\end{tabular}




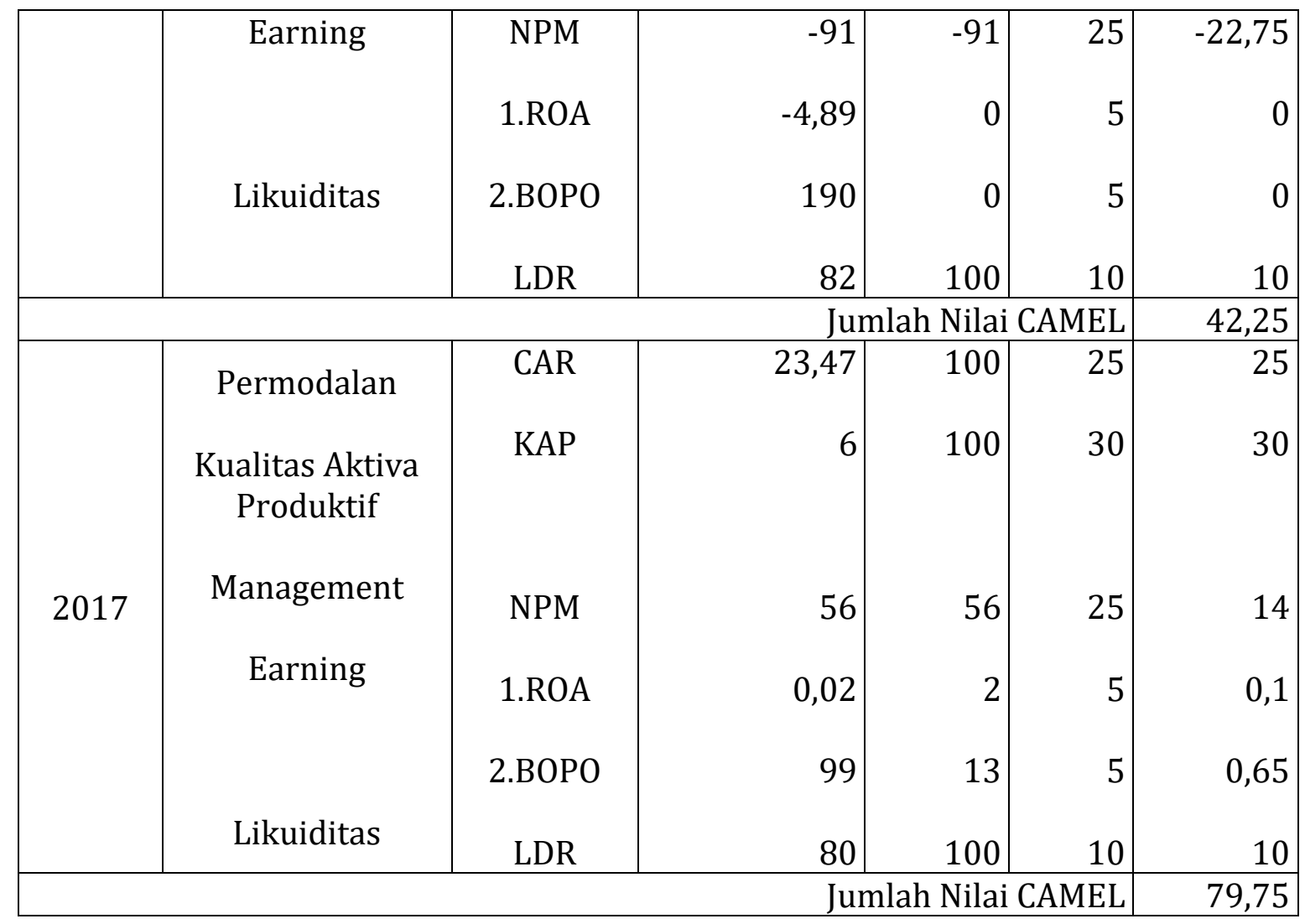

Sumber : Data Olahan 2018

1. Aspek Permodalan (Capital)

Rasio CAR yang dicapai oleh PT. Bank Artos Indonesia Tbk untuk tahun 2014 s/d 2017 sebesar 16,74\% $19,80 \%$ 24,22\% 23,47\%. Berdasarkan ketentuan yang telah ditetapkan oleh Bank Indonesia untuk predikat kesehatan rasio CAR harus dijaga pada batas aman (minimal 8\%) sedangkan rasio CAR yang diperoleh PT. Bank Artos Indonesia Tbk adalah 16,74\% $19,80 \% 24,22 \% 23,47 \% \geq 12 \%$ maka PT. Bank Artos Indonesia Tbk mendapat predikat SANGAT SEHAT dari segi Permodalan.

2. Aspek Kualitas Aktiva (Asset Quality)

Rasio Kualitas Aktiva Produktif (KAP) yang dicapai oleh PT. Bank Artos Indonesia Tbk untuk tahun 2014 s/d 2017 sebesar 4\%, 5\%, 7\%, 6\%. Berdasarkan ketentuan yang telah ditetapkan oleh Bank Indonesia untuk predikat kesehatan rasio KAP harus dijaga pada batas aman (maksimal 3\%) sedangkan rasio KAP yang diperoleh PT. Bank Artos Indonesia Tbk adalah 4\%, 5\%, 7\%, 6\% $\geq 3 \%$ maka PT. Bank Artos Indonesia Tbk mendapat predikat CUKUP SEHAT dari segi Kualitas Aktiva Produktif.

3. Aspek Manajemen (Management) Rasio Net Profit Margin (NPM) yang dicapai oleh PT. Bank Artos Indonesia Tbk untuk tahun $2014 \mathrm{~s} / \mathrm{d}$ 2017 sebesar 75\%, -69\%, -91\%, 56\%. Untuk tahun 2014 rasio NPM $<81 \%$ masuk dalam kategori CUKUP SEHAT, tahun 2015 dan 2016 rasio NPM < 51\% masuk dalam kategori TIDAK SEHAT, sedangkan untuk tahun 2017 rasio NPM < 66\% masuk dalam kategori KURANG SEHAT.

4. Aspek Rentabilitas (Earnings)

a. Return On Asset (ROA) 
Rasio ROA yang dicapai oleh PT. Bank Artos Indonesia Tbk untuk tahun 2014 s/d 2017 sebesar 0,25\% 0,01\% $\quad-4,89 \% \quad$ 0,02\%. Berdasarkan ketentuan yang telah ditetapkan oleh Bank Indonesia untuk predikat kesehatan rasio ROA harus dijaga pada batas aman diatas 1,25\%. sedangkan rasio ROA yang diperoleh PT. Bank Artos Indonesia Tbk adalah 0,25\% 0,01\% - -4,89\% 0,02\% < 0,50\% maka PT. Bank Artos Indonesia Tbk mendapat predikat KURANG SEHAT dari segi ROA.

b. Beban Operasional terhadap Pendapatan Operasional (BOPO)

Rasio BOPO yang dicapai oleh PT. Bank Artos Indonesia Tbk untuk tahun 2014 s/d 2017 sebesar 98\% $100 \% \quad 143 \% \quad 99 \%$. Berdasarkan ketentuan yang telah ditetapkan oleh Bank Indonesia untuk predikat kesehatan rasio BOPO harus dijaga pada batas aman (maksimal 95\%) sedangkan rasio BOPO yang diperoleh PT. Bank Artos Indonesia Tbk adalah 98\% 100\% 143\% 99\% $\geq 97 \%$ maka PT. Bank Artos Indonesia Tbk mendapat predikat TIDAK SEHAT dari segi BOPO.

5. Faktor Likuiditas (Liquidity)

Loan to Deposit Ratio (LDR) yang dicapai oleh PT. Bank Artos Indonesia Tbk untuk tahun $2014 \mathrm{~s} / \mathrm{d}$ 2017 sebesar 100\%, 88\%, 82\%, 80\%. Berdasarkan ketentuan yang telah ditetapkan oleh Bank Indonesia untuk predikat kesehatan rasio LDR harus dijaga pada batas aman (maksimal $85 \%$ ) sedangkan rasio LDR yang diperoleh PT. Bank Artos Indonesia Tbk untuk tahun $2014 \& 2015$ adalah $100 \%$ \& 88\% > 85\% maka PT. Bank Artos Indonesia Tbk mendapat predikat CUKUP SEHAT dan untuk tahun 2016 \& 2017 adalah 82\% \& $80 \%<85 \%$ mendapat predikat SEHAT dari segi likuiditas.

Berdasarkan tabel diatas, yakni hasil perhitungan nilai rasio CAMEL, maka dapat disajikan hasil penilaian kesehatan keuangan dengan rasio CAMEL khususnya dalam tahun 2014 s/d tahun 2017, yang dapat dilihat melalui tabel berikut ini : 
Tabel 15. Hasil Penilaian Tingkat Kesehatan PT. Bank Artos Indonesia Tbk.Tahun 2014 s/d 2017

\begin{tabular}{|c|c|c|}
\hline Tahun & Nilai CAMEL & Tingkat Kesehatan \\
\hline 2014 & 82,25 & Sehat \\
\hline 2015 & 47,80 & Tidak Sehat \\
\hline 2016 & 42,25 & Tidak Sehat \\
\hline 2017 & 79,75 & Cukup Sehat \\
\hline
\end{tabular}

Sumber : Data Olahan (2018)

Hasil Penelitian menunjukkan bahwa Analisis CAMEL secara keseluruhan dari perhitungan rasio pada PT. Bank Artos Indonesia Tbk untuk tahun 2014 mendapat predikat "SEHAT". tahun 2015 dan 2016 kondisi tingkat kesehatan bank dinyatakan "TIDAK SEHAT" dan tahun 2017 mendapatkan predikat "CUKUP SEHAT".

\section{KESIMPULAN}

Berdasarkan hasil penelitian dan pembahasan pada masing-masing faktor CAMEL secara keseluruhan dapat disimpulkan bahwa PT. Bank Artos Indonesia Tbk dalam kondisi TIDAK SEHAT. Hal ini dikarenakan Manajemen belum mampu mengelola dana secara efisien, dapat dilihat dari laporan keuangan bank bahwa beban-beban yang dikeluarkan oleh bank Artos Indonesia sangat besar kemudian kredit bermasalah pada bank ini juga cukup besar.

Berdasarkan analisis dari kesimpulan yang telah penulis kemukakan diatas mengenai Analisis Tingkat Kesehatan Bank dengan menggunakan Metode CAMEL pada PT. Bank Artos
Indonesia Tbk. Penulis dapat memberikan saran sebagai berikut :

1. Dalam rangka meningkatkan tingkat kesehatannya, disarankan PT. Bank Artos Indonesia Tbk terus memperkuat kegiatan usahanya agar jumlah aset yang dimiliki semakin meningkat.

2. Kepada manajemen PT. Bank Artos Indonesia Tbk diharapkan melakukan kinerja keuangannya dengan menggunakan metode CAMEL secara periodik, hal ini dimaksudkan untuk dapat meningkatkan kinerja keuangan

3. dimasa yang akan datang dan kemampuan manajemen juga harus ditingkatkan dalam pengelolaan dana, serta dalam mengatur kegiatan yang ada di bank.

\section{DAFTAR PUSTAKA}

Bank Indonesia (2015), Kamus Perbankan Bank Indonesia, (online), www.bi.go.id/id/Kamus.aspx 
Bank Indonesia (2004), Peraturan Bank Indonesia No. 6/10/PBI/2004 Tentang Sistem Penilaian Tingkat Kesehatan Bank Umum. 12 April 2004.

Bank Indonesia (2004), Surat Edaran Bank Indonesia No. 6/23/DPNP tanggal 31 Mei 2004, Perihal Sistem Penilaian Tingkat Kesehatan Bank Umum, (online), (http://www.bi.go.id)

Bank Indonesia (2011), Peraturan Bank Indonesia No. 13/3/PBI/2011 Peringkat Komposit Setiap Komponen.

Bank Indonesia, Surat Keputusan Direksi Bank Indonesia 31/147/KEP/DIR Tentang Perhitungan Nilai Kredit. tanggal 12 November 1998.

K. (2014), Bank Dan Lembaga Keuangan Lainnya. Ed. Revisi, Cetakan Keenambelas, Jakarta : PT. Raja Grafindo Persada

K. (2017), Analisa Laporan Keuangan. Edisi Satu sampai Sepuluh, Cetakan Kesepuluh,Jakarta : PT. Rajawali Raja Grafindo Persada

P, F, (2012), Manajemen Dana Dan Kesehatan Bank. Jakarta : Rineka Cipta.

S,H. (2016). “Analisis Tingkat Kesehatan Bank Dengan Menggunakan Rasio CAMEL (Studi Kasus Pada Bank Rakyat Indonesia (Pesero) Tbk". Jurnal Skripsi, (Online), (http://media.neliti.com)

S, R. (2017) "Analisis Tingkat Kesehatan Bank Dengan Menggunakan Metode CAMEL (Studi Kasus Pada PT. Bank Mandiri Tbk)". Jurnal
EMBA, Vol.5,No.2,Juni 2017, Hal.2143-2149.

W, B, (2014), Mudah Membaca Laporan Keuangan. Jakarta : Raih Asa Sukses 